https://www.amerabra.org; https://fspu.uitm.edu.my/cebs; https://www.emasemasresources.com/

$5^{\text {th }}$ ABRA International Conference on Quality of Life

Holiday Villa Langkawi, Langkawi Island, Malaysia, 15-16 Dec 2021

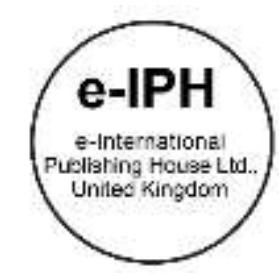

\title{
Conservation Aspects on Developing Geotourism for Young Tourists during the Covid-19 Pandemic in Silalahi Village
}

\author{
Nurlisa Ginting ${ }^{123}$, Nurinayat Vinky Rahman ${ }^{123}$, Antonella Trombadore ${ }^{4}$ \\ ${ }^{1}$ Department of Architecture, Faculty of Engineering, Universitas Sumatera Utara, Medan, Indonesia, ${ }^{2}$ Lake Toba \& Sustainable \\ Tourism Working Group, Universitas Sumatera Utara, Medan, Indonesia, ${ }^{3}$ Monitoring Centre of Sustainable Tourism Observatory \\ (MCSTO), Universitas Sumatera Utara, Medan, Indonesia, ${ }^{4}$ DiDA Dipartimento di Architettura, University of Florence, Florence, Italy \\ nurlisa@usu.ac.id, n.vinky@usu.ac.id, antonella.trombadore@unifi.it \\ Tel: +62811608102
}

\begin{abstract}
Sustainable tourism is a tourism concept that provides sustainability for tourist destinations in the future, where geo-tourism is part of it. Geotourism development in conservation is an action to protect the geo-site from damage. The research area is located in Silalahi Village on the coast of Toba Caldera, rich in geodiversity and historical-cultural suitable for young visitors. The factors of this study, i.e., Environmental Conservation Activities and Cultural Conservation Activities, were investigated using the mixed method. This study shows geotourism development based on the conservation aspect for youth tourists during the COVID-19 pandemic in Silalahi Village.
\end{abstract}

Keywords: Geotourism; conservation aspects; young tourists; COVID-19

eISSN: 2398-4287@ 2021. The Authors. Published for AMER ABRA cE-Bs by e-International Publishing House, Ltd., UK. This is an open access article under the CC BYNCND license (http://creativecommons.org/licenses/by-nc-nd/4.0/). Peer-review under responsibility of AMER (Association of Malaysian Environment-Behaviour Researchers), ABRA (Association of Behavioural Researchers on Asians/Africans/Arabians) and cE-Bs (Centre for Environment-Behaviour Studies), Faculty of Architecture, Planning \& Surveying, Universiti Teknologi MARA, Malaysia.

DOI: https://doi.org/10.21834/ebpj.v6i18.3063

\subsection{Introduction}

Tourism is one of the drivers of economic development in Indonesia. The wealth of natural and cultural resources is the main attraction in tourism (Astuti, 2018). However, the spread of COVID-19 has an impact on the tourism sector. Therefore, tourist destinations must consistently attract tourists by implementing innovations through digitalisation (UNWTO, 2020).

The concept of sustainable tourism challenges the times because it continues to create a sustainable tourist destination for the present or the future that impacts the environment, society, culture, and economy (Menparekraf/Baparekraf RI, 2021). In sustainable development, there are three dimensions that are part of the 2030 Agenda and Sustainable Development Goals (SDGs) support, namely economic, social and environmental (UN, 2015). In achieving the sustainable development goals (SDGs) support that is coherent and inseparable, active participation and involvement of the community, sectors, and the geoscience community is very necessary (Catana \& Brilha, 2020) to show 11 main geological aspects in supporting the SDGs, which include geotourism, geo-education (Gill, 2017; Lee \& Jayakumar, 2021) and geo-conservation, this is a three-pillar approach in geopark (UNESCO, 2006).

Geotourism is part of a form of sustainable tourism where the main focus is through natural geological experiences through understanding the environment as well as appreciation, conservation, and attention to the preservation of local wisdom (Prykhodchenko, 2017; Dowling, 2014).

eISSN: 2398-4287C 2021. The Authors. Published for AMER ABRA cE-Bs by e-International Publishing House, Ltd., UK. This is an open access article under the CC BYNCND license (http://creativecommons.org/licenses/by-nc-nd/4.0/). Peer-review under responsibility of AMER (Association of Malaysian Environment-Behaviour Researchers), ABRA (Association of Behavioural Researchers on Asians/Africans/Arabians) and cE-Bs (Centre for Environment-Behaviour Studies), Faculty of Architecture, Planning \& Surveying, Universiti Teknologi MARA, Malaysia.

DOI: https://doi.org/10.21834/ebpj.v6i18.3063 
Development of geotourism in conservation to protect geo-sites from damage by implementing protection and management measures. Tourism environmental conditions can be damaged if used excessively, so that protection or conservation is needed so that tourism remains sustainable in the future (Hermawan \& Brahmanto, 2017). Conservation is not only carried out by tourism managers but also involves young tourists.

The research area is located in Silalahi Village is one of the villages located on the coast of Caldera Toba which has been ratification as a Global Geopark by UNESCO (Manurung \& Sinabariba, 2020) with extraordinary natural beauty. Silalahi Village provides many tourism products that are suitable for young visitors. Thus, Silalahi Village has become a favourite destination for young tourists and a leading destination in Dairi Regency. However, the development of geotourism based on conservation aspects during the pandemic in Silalahi village is still minimal. Therefore, this study aims to determine the aspect of conservation-based geotourism for young tourists during the COVID-19 pandemic in Silalahi Village.

\subsection{Literature Review}

\subsection{Geotourism}

Geological, biological, and cultural diversity is an essential asset in developing sustainable tourism, especially geo-tourism, which has the main goal in natural areas, namely geological and landscape aspects (Wulung et al., 2021; Dewar, 2011). Geotourism is the provision of services and interpretations to obtain information about the geology and geomorphology of a tourist site (Kubalíková, 2019; Hose, 1995). Geotourism can fulfil the wishes of tourists. Provide a positive impact on the environment and local communities in developing the economy in the area (Ginting et al., 2021).

Geotourism is a concept that is present in contemporary tourism to create a fun and meaningful travel experience. Geotourism has five basic principles in its development, namely: (1) geo-heritage; (2) geo-conservation/sustainability; (3) geo-interpretation/education; (4) benefiting local communities; (5) providing satisfaction to tourists (Herrera-Franco et al., 2020). Geotourism encourages a sense of care for the perpetrators of its activities so that they care to want to participate and protect, conserve biodiversity and geo heritage, namely "geographical conservation" (Sadry, 2020).

\subsection{Conservation}

Conservation aspects play an essential role in the development of geotourism (Ginting et al., 2020). Conservation is an activity to maintain, protect, and manage a place so that future generations can still enjoy it. Conservation consists of environmental conservation and cultural conservation. Environmental conservation is a method/process of protecting certain areas from damage and pollution (Runa et al., 2020). Meanwhile, efforts to preserve the culture of cultural/artefact preservation and social preservation. However, the two do not differ in the purpose of their preservation (Runa et al., 2020; Appleyard, 1979). Cultural conservation consists of two interrelated dimensions. First, the backward dimension is an effort to protect and preserve local wisdom found in the community. The second is the future dimension, which is to maintain the culture so that it still exists (Supriono, 2020).

The phenomenon of the COVID-19 pandemic makes activities stop instantly and becomes an opportunity for natural ecosystems to rest after intensive use for tourism (Hakim, 2020). The decline in tourist visits due to social distancing rules has led to a reduction in waste generation, and site maintenance can be improved during this pandemic (Zambrano-Monserrate, 2020).

Indicators that include environmental conservation are water and waste management in tourist destinations, environmental conservation activities involving young tourists, pollution caused by young tourists, and the intensity of facilities and infrastructure in tourist destinations. Development and maintenance of facilities in tourist areas such as hotels, restaurants, resorts and natural or cultural tourism areas (Kariminia et al., 2018). Indicators that include cultural conservation are cultural activities involving young tourists, the positive and negative influence of young tourists on the local community's culture, and how to protect local culture by involving young tourists (Table 1).

Table 1. Aspects of Conservation

\begin{tabular}{|c|c|c|}
\hline Factors & Indicator & COVID-19 elements \\
\hline \multirow[t]{5}{*}{ Environmental conservation activities } & $\begin{array}{l}\text { Water and waste management in } \\
\text { tourist destinations }\end{array}$ & \multirow{6}{*}{$\begin{array}{l}\text { Cleanliness } \\
\text { Health } \\
\text { Safety } \\
\text { Environment Sustainability }\end{array}$} \\
\hline & $\begin{array}{l}\text { Environmental conservation } \\
\text { activities involving young tourists }\end{array}$ & \\
\hline & & \\
\hline & Pollution caused by young tourists & \\
\hline & $\begin{array}{l}\text { The intensity of facilities and } \\
\text { infrastructure in tourist destinations }\end{array}$ & \\
\hline Cultural conservation activities & $\begin{array}{l}\text { Cultural activities involving young } \\
\text { tourists }\end{array}$ & \\
\hline
\end{tabular}




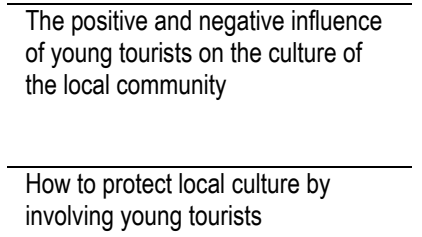

(Source: Author)

\subsection{Young Tourists}

Young tourists are an important factor for the world of global tourism (Baum \& Thompson, 2007; Yunusovich, 2018). Young tourists or the millennial generation have a significant social and economic impact not only on the present but also on the future of the tourism industry (Cavagnaro \& Staffieri, 2015; Staffieri et al, 2018). Union World Trade Organization of Nations (UNWTO) \& Worldwide Youth in Science and Engineering (WYSE) in 2011 estimated that young tourists would increase to 300 million trips by 2020 and account for one-sixth of the global tourism market (Moisa, 2010; Preko et al, 2019).

Young tourists are a journey carried out by people aged 16-29 years independently in less than one year to fulfil the desire to see other cultural activities and increase knowledge by learning directly from the external environment (UNWTO \& WYSE Travel Confederation, 2008). Young tourists also prioritize meeting with other tourists so that international friendships are established and have a tendency to choose cheap restaurants and lodging accommodation (Haigh, 1995; Youth Tourism, 2012; Han et al, 2018) also like tourist destinations in the form of adventure (Marpaung, 2002; Hermawan \& Brahmanto, 2017).

Young tourists consist of several types (but not limited to): backpacking travel, volunteers, adventure trips, work trips, youth/foreign student exchanges, vacations with friends, learning foreign languages to a specific country, internship trips to experience the local culture, getting education or work, explore places visited or to develop themselves (Clarke, 2004; Han et al., 2017b; Kiatkawsin \& Han, 2017; Maoz, 2006; Obenour, Patterson, Pedersen, \& Pearson, 2004; Youth Tourism, 2012).

\subsection{Methodology}

\subsection{Research Area}

The location of the research area is in Silalahi Village, Silahisabungan District, Dairi Regency, North Sumatra Province. Silalahi Village is also a village located in the Toba Caldera area, part of the Global Geopark, established at the 209th session of the UNESCO Executive Council in Paris, France, on July 7, 2020 (Simatupang \& Ismanto, 2021). Toba Caldera is one of the government's focuses on tourism development (Hutauruk et al, 2018). The tourist area of Silalahi Village is rich in geodiversity, history and culture, such as the Tomb of Raja Silahisabungan, Rohiana Beach Public Baths, Campground, and Silalahi Beach. Various tourist attractions, both natural and cultural tourism, attract young tourists to come.

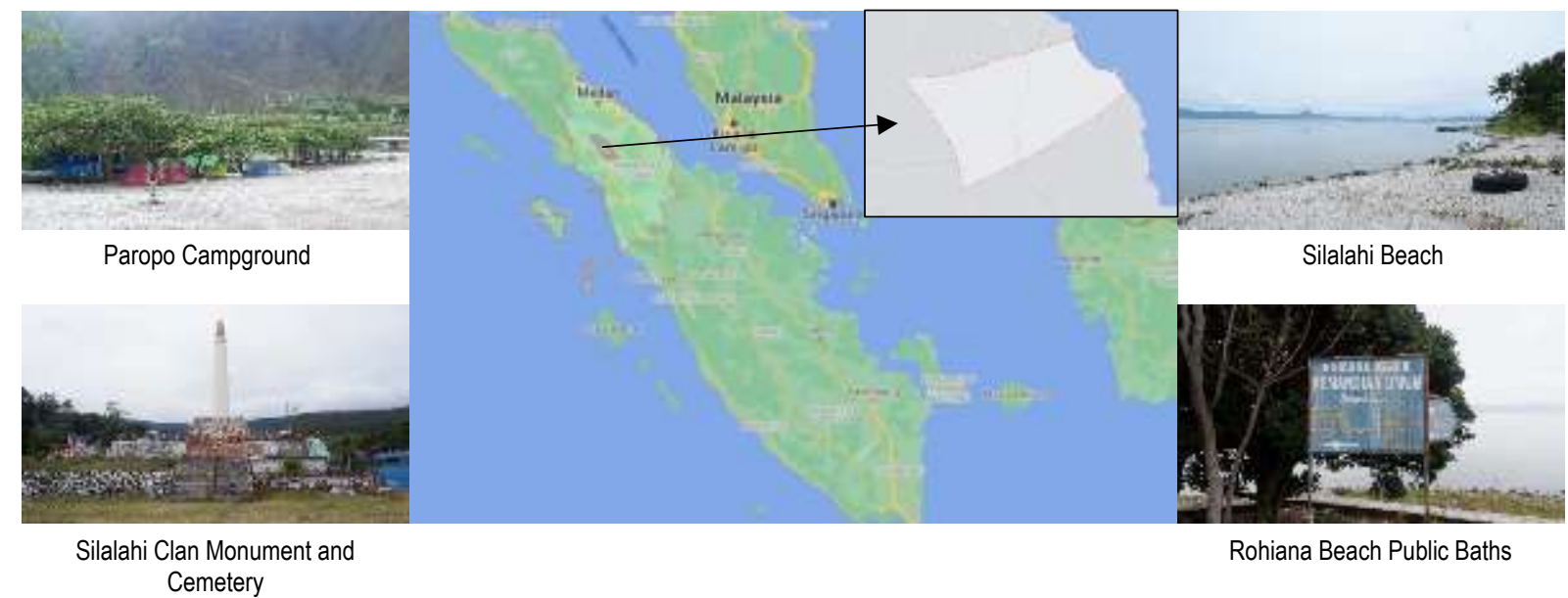

Fig. 1. Research Area

(Source: Author)

\subsection{Methods}

The variables of this research, namely Environmental Conservation Activities and Cultural Conservation Activities, were investigated using mixed methods. This study combines qualitative and quantitative methods through field observations, in-depth interviews with seven stakeholders, and distributing questionnaires to collect perceptions of young tourists.

The questionnaire data collection period is from August - October 2021, by distributing 100 questionnaires through social media, namely Instagram, WhatsApp, etc., in the form of a google form that reaches young tourists aged 15-29 years and has visited Silalahi 
Village this one year. The questionnaire was distributed in a structured manner with closed-ended questions with a 5-point scale ranging from disagree (1) to strongly agree (5) in measuring the results of the questionnaire given in percentages and the average value for the geotourism conservation aspect. The conservation aspect factors are analysed on indicators: water and waste management in tourist destinations, environmental conservation activities involving young tourists, pollution caused by young tourists, and the intensity of facilities and infrastructure in tourist destinations, cultural activities involving young tourists, the positive and negative influence of young tourists on the local community's culture, and how to protect local culture by involving young tourists.

Field observations and in-depth interviews were carried out on October 20 - 22, 2021. Direct observations were carried out to obtain physical data of the research area in the form of photos of architectural styles, uses, culture, activities and others. In-depth interviews with key informants, namely the tourism office, local government, tourism managers, academics, and hotels.

\subsection{Findings}

\subsection{Respondents}

This study involved 100 respondents of young tourists who visited Silalahi village during the new normal period. The results showed that the young tourist respondents had an average age range of 20-24 years by $61 \%$, then ages $25-29$ years by $27 \%$ and the smallest with an age range of $15-19$ years by $12 \%$. The majority of respondents last education was Bachelor S1/Diploma (56\%), High School/Equivalent $(42 \%)$, and Masters S2 (2\%). While the majority of the work is Student/College Student (45\%), Private Employee (17\%), Entrepreneur $(15 \%)$, Employee/Labour (11\%), Not Working (10\%), and Civil Servant ( $2 \%)$. Most of the tourist objects visited by respondents were Silalahi Beach (42\%), Paropo Campground (37\%), Silalahi Clan Monument and Cemetery (14\%), and Rohiana Beach Public Baths $(7 \%)$. Differences in age range, education, and occupation will produce diverse mindsets that affect how people take action (Ginting et al., 2020).

\subsection{Conservation Aspect}

Paropo Campground, Silalahi Clan Monument and Cemetery, Silalahi Beach, Rohiana Beach Public Baths are geotourism sites that represent tourism in Silalahi village. The data results show the response of young tourists to geotourism in Silalahi village during the COVID-19 pandemic from environmental and cultural conservation activities shows an average value of more than 3.

In the aspect of environmental conservation, the questions that get the highest average score based on Table 2 are Q4 "I participate in maintaining the environment in terms of cleanliness during the pandemic" (Mean = 4.33), Q5 "When I implement health protocols, I participate in providing a sense of security to other young tourists" (Mean = 4.42), Q8 "I feel worried when I'm around other young tourists who don't follow health protocols" (Mean $=4.47$ ). For an indicator of water and waste management in tourist destinations the average value is quite good (Mean $=3.19$ ).

Based on this, it can be concluded that young tourists maintain the cleanliness of the environment and facilities in geotourism areas during the pandemic. Young tourists agree that implementing health protocols makes them feel safe and comfortable while travelling. But unfortunately, this is not in line with its implementation in the field by young tourists when travelling, as shown in Table 2 Q7 with a score of 2.27 "When I'm at a geotourism location I don't pay attention to health protocols".

Table 2. Environmental Conservation Activities Aspects of Geotourism with COVID-19 Elements

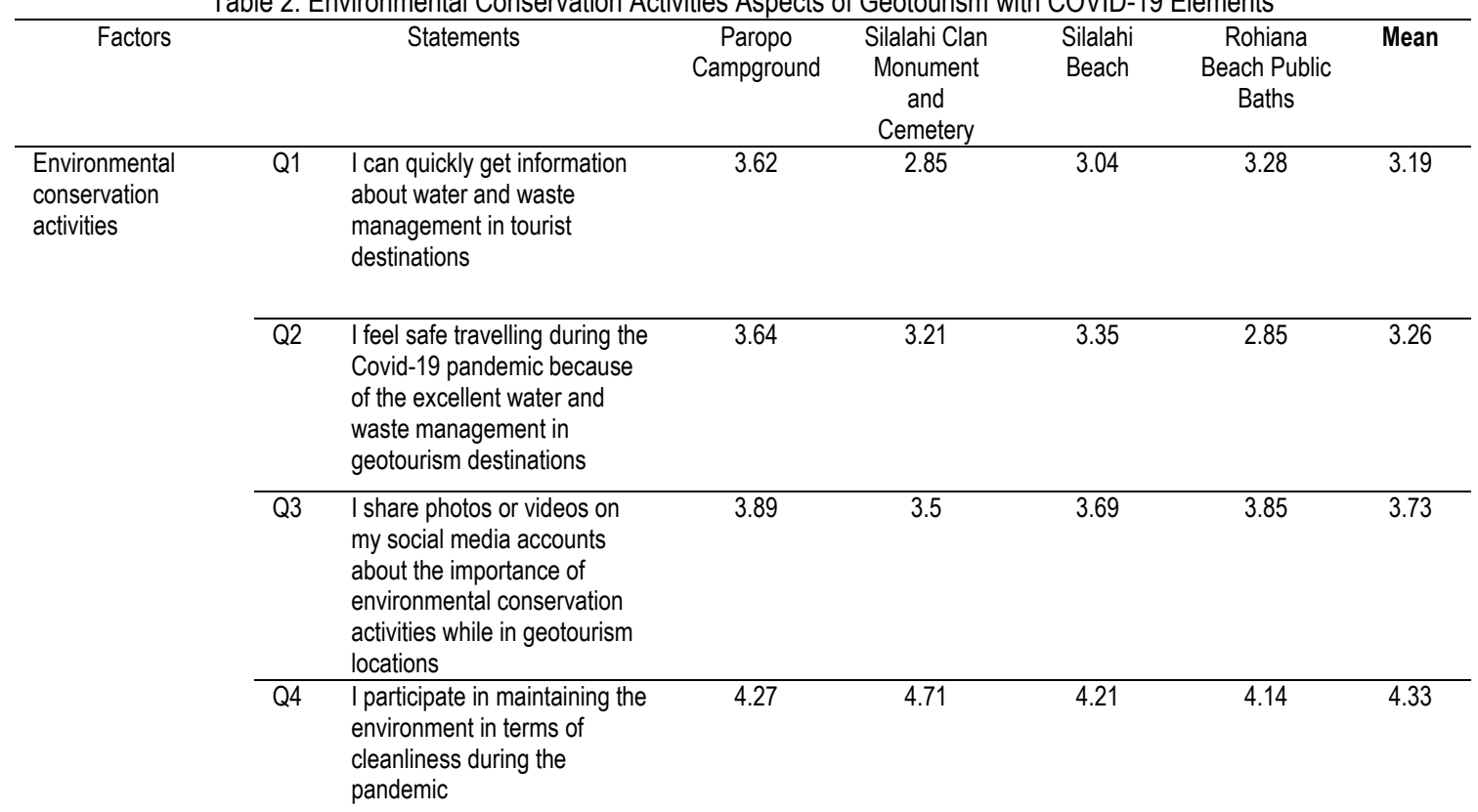




\begin{tabular}{|c|c|c|c|c|c|c|}
\hline Q5 & $\begin{array}{l}\text { When I implement health } \\
\text { protocols, I participate in } \\
\text { providing a sense of security } \\
\text { to other young tourists }\end{array}$ & 4.27 & 4.57 & 4.30 & 4.57 & 4.42 \\
\hline Q6 & $\begin{array}{l}\text { When sharing content on } \\
\text { social media, I ignore the state } \\
\text { of my surroundings }\end{array}$ & 3.29 & 2.71 & 2.71 & 1.85 & 2.64 \\
\hline Q7 & $\begin{array}{l}\text { When I'm at a geotourism } \\
\text { location, I ignore health } \\
\text { protocols }\end{array}$ & 3.05 & 1.92 & 2.54 & 1.57 & 2.27 \\
\hline Q8 & $\begin{array}{l}\text { I feel worried when I'm around } \\
\text { other young tourists who don't } \\
\text { follow health protocols }\end{array}$ & 4.40 & 4.64 & 4 & 4.85 & 4.47 \\
\hline Q9 & $\begin{array}{l}\text { I can get access to information } \\
\text { about existing facilities and } \\
\text { infrastructure in geotourism } \\
\text { destinations }\end{array}$ & 3.91 & 3.57 & 3.38 & 3.42 & 3.57 \\
\hline Q10 & $\begin{array}{l}\text { I am involved in maintaining } \\
\text { the cleanliness of the facility } \\
\text { when I am in a geotourism } \\
\text { destination }\end{array}$ & 4.21 & 4.21 & 4.16 & 4.14 & 4.18 \\
\hline \multirow[t]{2}{*}{ Q11 } & $\begin{array}{l}\text { Other young tourists and I } \\
\text { participate in maintaining } \\
\text { facilities at tourist destinations } \\
\text { so that we give each other a } \\
\text { sense of security while } \\
\text { travelling during a pandemic }\end{array}$ & 4.13 & 4.21 & 4.09 & 4.28 & 4.17 \\
\hline & Mean & 3.88 & 3.64 & 3.59 & 3.53 & 3.66 \\
\hline
\end{tabular}

In the aspect of cultural conservation activities, the questions that get the highest score based on Table 3 are Q13 "I apply health protocols when carrying out cultural conservation activities at geotourism locations" (Mean $=4.20)$, Q14 "When I apply the health protocol, I also provide a sense of security to other young tourists in carrying out cultural conservation activities at geotourism locations" (Mean = 4.29), Q19 "My participation in giving a sense of security to other visitors, i.e. by complying with health protocols when in cultural activities" $($ Mean $=4.30)$. The data shows that young tourists play a role in cultural conservation activities and implement health protocols.

Table 3. Cultural Conservation Activities Aspects of Geotourism with COVID-19 Elements

\begin{tabular}{|c|c|c|c|c|c|c|c|}
\hline Factors & & Statements & Paropo & Silalahi Clan & Silalahi & & Mean \\
\hline \multirow[t]{4}{*}{$\begin{array}{l}\text { Cultural } \\
\text { conservation } \\
\text { activities }\end{array}$} & Q12 & $\begin{array}{l}\text { There are cultural activities } \\
\text { broadcast online involving } \\
\text { tourists }\end{array}$ & 3.72 & 3.85 & 3.38 & 4.14 & 3.77 \\
\hline & Q13 & $\begin{array}{l}\text { I apply health protocols when } \\
\text { carrying out cultural } \\
\text { conservation activities at } \\
\text { geotourism locations }\end{array}$ & 4.24 & 4.21 & 4.09 & 4.28 & 4.20 \\
\hline & Q14 & $\begin{array}{l}\text { When I apply the health } \\
\text { protocol, I also provide a } \\
\text { sense of security to other } \\
\text { young tourists in carrying out } \\
\text { cultural conservation activities } \\
\text { at geotourism locations }\end{array}$ & 4.29 & 4.57 & 4.16 & 4.14 & 4.29 \\
\hline & Q15 & $\begin{array}{l}\text { I see my arrival or other young } \\
\text { tourists have an effect on the } \\
\text { cleanliness of tourist } \\
\text { destinations during the } \\
\text { pandemic }\end{array}$ & 4.32 & 4.07 & 4 & 4.14 & 4.13 \\
\hline
\end{tabular}




\begin{tabular}{|c|c|c|c|c|c|c|c|}
\hline & Q16 & $\begin{array}{l}\text { I heard the local people's } \\
\text { worried about the arrival of } \\
\text { young tourists like me who } \\
\text { visited during the pandemic }\end{array}$ & 3.51 & 3.07 & 2.92 & 3.14 & 3.16 \\
\hline & Q17 & $\begin{array}{l}\text { I contribute to the role of } \\
\text { cultural conservation in the } \\
\text { geotourism destinations when } \\
\text { I visit by sharing information } \\
\text { through social media accounts } \\
\text { about the cultural activities I } \\
\text { do }\end{array}$ & 4.05 & 3.57 & 3.59 & 3.28 & 3.62 \\
\hline & Q18 & $\begin{array}{l}\text { I participate in carrying out } \\
\text { cultural activities by } \\
\text { implementing health protocols }\end{array}$ & 4.02 & 4.07 & 3.95 & 4.14 & 4.04 \\
\hline & Q19 & $\begin{array}{l}\text { My participation in giving a } \\
\text { sense of security to other } \\
\text { visitors, i.e. by complying with } \\
\text { health protocols when in } \\
\text { cultural activities }\end{array}$ & 4.40 & 4.50 & 4.16 & 4.14 & 4.30 \\
\hline $\begin{array}{l}\text { Value Format: } \\
1=\text { strongly disagree } \\
5=\text { strongly agree }\end{array}$ & & Mean & 4.07 & 3.99 & 3.78 & 3.92 & 3.94 \\
\hline
\end{tabular}

(Source: Author)

\subsection{Discussion}

\subsection{Environmental Conservation Activities}

\section{Water and waste management in tourist destinations}

Good management of water resources is one of the keys to sustainable tourism, and supply and demand management is the basis of most studies on water management (Yoon, Sauri, \& Rico, 2018). The tourism industry is an area with significant water consumption, and therefore, conservation has become an essential issue in water management (Gössling, 2015). The biggest challenge in managing water resources is water conservation so that it is sustainable so that future generations can enjoy it because water can be reduced and polluted. Silalahi Village itself does not yet have a water management system that is not yet optimal. Water pollution caused by young tourists is generated by plastic waste after camping or travelling. In tourism development, both quantitatively and qualitatively, it's known that it can affect water supplies (Becken, Rajan, Moore, McLennan, \& Garofano, 2014; Stonich, 1998; Cole et al., 2020). Some of the negative impacts that can be generated from tourism activities include the depletion of water, water pollution, and competition for water (Becken, 2014; Benge \& Neef, 2018; Cole, 2012; LaVanchy, 2017; LaVanchy \& Taylor, 2015; Noble et al., 2012; Strauß, 2011).

Water pollution does not only come from young tourists. However, floating net cages on the shores of the lake are also the cause (Fig. 2). It will pollute the water and the air because the smell of waste will produce a bothersome smell. The reason tourists want to come to natural attractions is to get the natural quality that is far from pollution. If this continues, it will affect the level of tourist visits, both local and foreign.

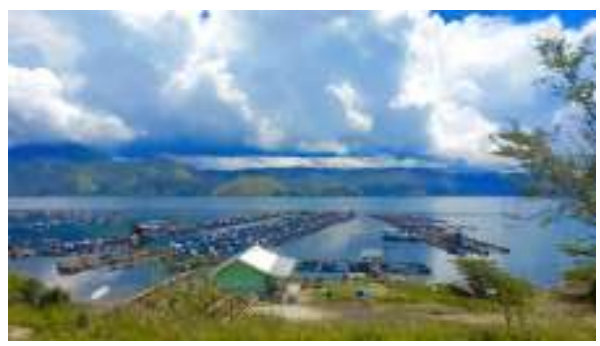

Fig. 2. Floating Net Cages (Source: Author)

According to law no. 18 of 2008, waste management is a structured activity carried out comprehensively and sustainably, including waste reduction and processing. Waste management is managing items that are no longer used or thrown away (Yousefloo \& Babazadeh, 2020).

Waste management in Silalahi Village is also not optimal. There is no place to recycle waste into valuable items for life because the accumulation of garbage can pollute the environment and become a social problem. Waste management that is carried out optimally is intended to reduce waste accumulation, overcome social and environmental problems for waste, and properly manage waste to produce energy sources and recycle waste into goods that are useful for life (Atmanti \& Purwanti, 2021). 
Comparing four tourist destinations, the availability of information regarding water and waste management in Silalahi is quite good (Paropo Campground $=3.62$; Silalahi Clan Monument and Cemetery = 2.85; Silalahi Beach = 3.04; Rohiana Beach Public Baths $=3.28$; Mean of four tourist destinations $=3.19$ ). Tourist attractions with the lowest rating from young tourists are the Monument and Tomb of the Silalahi Clan (Mean $=2.85)$.

"Domestic waste disposal is directly channelled into Lake Toba without any prior filtering." (Fig. 3) (Key Respondent: Silalahi Village Beach Tourism Manager, October 2021)

Pollution due to domestic waste in Lake Toba, especially the Silalahi Village area, has reached the status of moderately polluted water quality. It is feared that if there is no good sewage treatment system, the water quality status of Lake Toba will be heavily polluted (Tirtanadi, 2016).

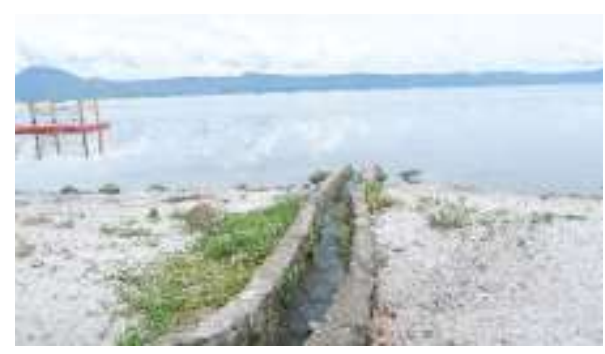

Fig. 3. Domestic waste

(Source: Author)

\section{Environmental conservation activities involving young tourists}

Conservation is an effort to prevent a crisis in the environment. Conservation must get serious attention (Sudiasmo \& Muspita, 2020). The awareness of young tourists about the importance of environmental conservation activities while at the geotourism location and then sharing these activities on their social media is quite good, with an average value from each study of tourist attractions (Mean $=3.73)$. The participation of young tourists in maintaining a clean environment during the pandemic shows a perfect number (Mean $=4.33$ ).

Based on the results of interviews, environmental conservation activities have been carried out in Silalahi Village. However, it is not done routinely. Young tourists will be more environmentally sustainable if they are actively invited to participate in conservation activities at the tourist destination (Han, Yu, \& Kim, 2018). Therefore, conservation activities must be carried out regularly so that young tourists become active in protecting the environment of the tourist destinations they visit.

"Nature lovers community activists have carried out environmental conservation activities, both students and tourists, namely planting trees and cleaning up trash around the lake or in the Silalahi Village environment. Residents in each village also carry out cooperation activities to clean the environment." (Key Respondent: Silalahi III village head staff, October 2021)

The Dairi Tourism Office also agrees that conservation has been carried out: "We have twice carried out conservation activities by involving the Kelompok Sadar Wisata (Pokdarwis) to clean the beaches Silalahi I, II, and III." (Key Respondent: Dairi Tourism Office, October 2021)

The development of conservation-based geotourism for young tourists is one way to preserve nature and culture. Where there are young tourists who are aware of the importance of conservation. In addition, young tourists have the will and will carry out conservation if they are informed in the right and correct way (Han et al., 2017).

\section{Pollution caused by young tourists}

Minimizing the impact of waste from tourism activities is one of the tourism principles (Tien et al., 2019). Based on the results of the questionnaire, young tourists said that they participated in maintaining the environment in terms of cleanliness during the pandemic (Mean $=4.33$ ). However, the results of the questionnaire were not following the conditions in the field. When the researchers conducted observations, it was found that there was still garbage scattered in several research locations, such as the Paropo Campground (Fig. 4). Even though the tour manager has provided a trash can, it has shown that young tourists are still less aware of maintaining the cleanliness of tourist destinations.

The most common waste found scattered in tourist sites is plastic waste. Plastic waste is a type of waste that is often found in tourist sites (Jang et al., 2014). Even though the nature of plastic waste is difficult to decompose (Andrady, 2011). If plastic waste is not managed correctly and allowed to accumulate, it can decrease the number of tourist visits (Hayati et al., 2020). Garbage scattered at tourist sites and not appropriately managed will make visitors uncomfortable (Atmanti \& Purwanti, 2021). 


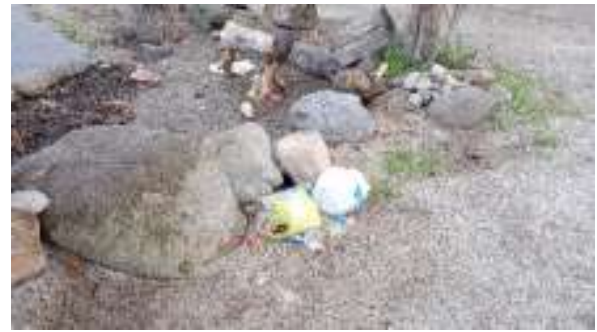

Fig. 4. Pile of Garbage at Paropo Campground (Source: Author)

\section{The intensity of facilities and infrastructure in tourist destinations}

According to young tourists, the ease of getting access to information about the availability of facilities and infrastructure in geotourism destinations is quite good (Mean $=3,57$ ). Young tourists participate in maintaining the cleanliness of the facilities very well (Mean $=4.18)$. The management has also provided facilities in tourist destinations such as toilets and rubbish bins (Fig. 5).

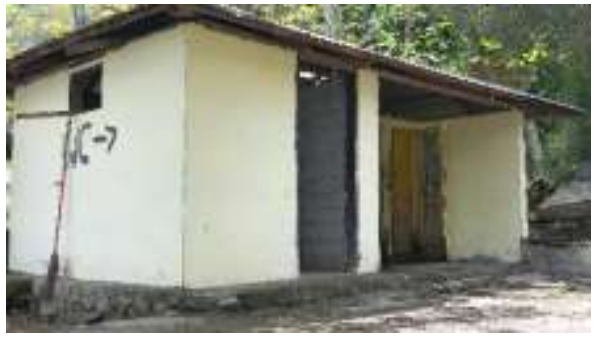

(a)

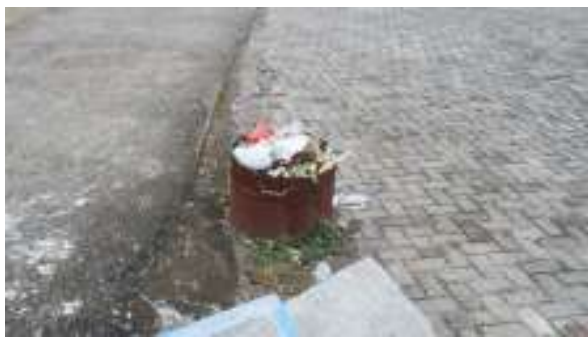

(b)

Fig. 5. (a) Toilets; (b) Rubbish Bin. (Source: Author)

Around the geotourism destinations, there is also a restaurant for Muslims, Musholla, and a homestay/hotel. All facilities are in good condition. Good and well-maintained facilities and infrastructure, in addition to meeting the needs of tourists in tourist destinations, also ensure that tourists maintain and care for the place (Hose, 2000; Newsome \& Dowling 2010).

Based on field observations, the provision of its sink is only available at Paropo Campground, while other tourist attractions do not yet exist (Fig. 6). Whereas one of the requirements in implementing health protocols in tourist attractions is the availability of a sink for washing hands. Even the hotel itself does not check the body temperature of tourists who come. The results of interviews with resource persons, the local government has provided socialisation about applying health protocols in tourist attractions. Unfortunately, there is no assistance fund provided to the managers of tourist destinations. They provide their sink so that not all tourist destinations apply health protocols.

"The provision of sinks during the pandemic exists. There is no aid fund from the government, but the tour manager makes his own (Key Respondent: Tourism Manager in Silalahi Village, October 2021)."

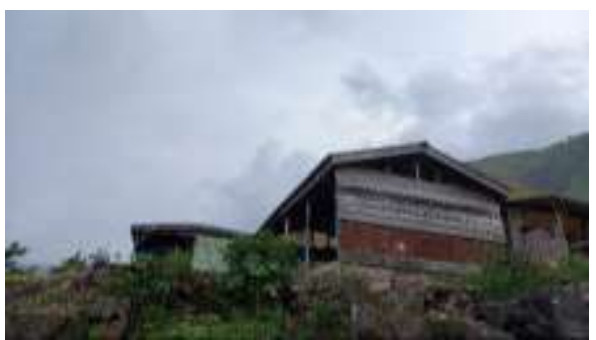

(a)

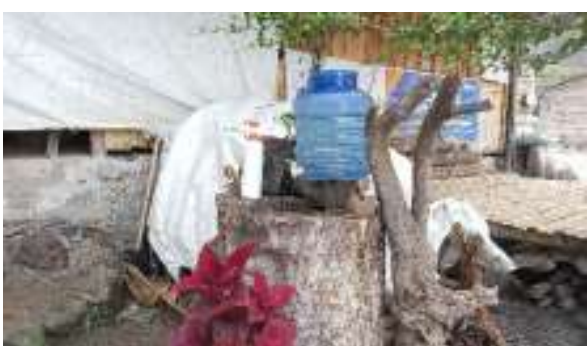

(b)

Fig. 6. (a) Musholla; (b) Sink (Source: Author)

\subsection{Cultural Conservation Activities}

Based on the questionnaire results, according to young tourists, there are cultural activities broadcast online that involve tourists (Mean = 3,77). When carrying out cultural preservation activities at geotourism locations, young tourists apply health protocols (Mean $=4.20$ ). Cultural activities are still preserved in Silalahi Village, marked by the presence of a dance studio. In addition, on big days at the Silalahi Clan Monument and Cemetery, dance performances are held (Fig. 7). Silalahi Clan Monument and Cemetery have also been designated as a cultural heritage building by the Culture \& Tourism Office of North Sumatra Province. Cultural heritage buildings are an asset that 
must be preserved because they are valuable objects from the past. They are contained in cultural artefacts, natural resources, art, architecture, history, economy, and socio-cultural values. Therefore, they have an essential role in influencing social and economic dynamics, both developed and developing countries (Umar \& Said, 2018).

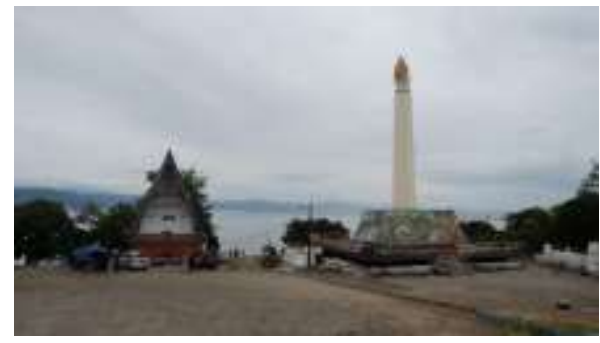

(a)

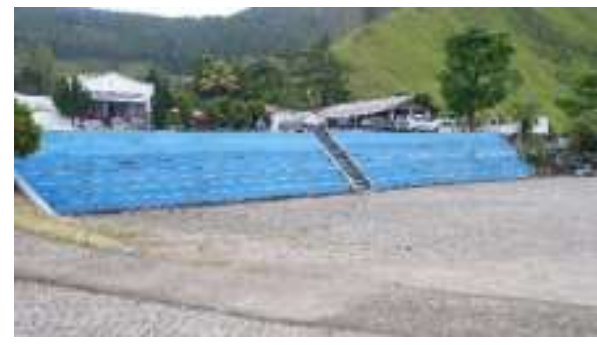

(b)

Fig. 7. (a) Silalahi Clan Monument and Cemetery; (b) Performance Dance Venue.

(Source: Author)

The contribution of young tourists to the role of cultural preservation in geotourism destinations when visiting Silalahi Village, namely by sharing information through social media accounts about the cultural activities they do, shows a fairly good score (Mean = 3.62). However, young tourists also have a negative impact on the cleanliness of tourist destination locations during the pandemic, with an average score (Mean $=4.13)$.

\subsection{Conclusion \& Recommendations}

This study found that the Silalahi village area can be developed into geotourism, especially in the aspect of environmental and cultural conservation. However, many things still need to be improved so that its development can be maximised. Environmental conservation carried out in Silalahi Village received a quite good average score from young tourists. However, the results of observations in the field indicate that the facts are not good because water and waste management in tourist destinations by the community is directly channelled to Lake Toba. For young tourists, the garbage they throw away can pollute the lake water. This can have a negative impact on the environment. In addition, the awareness of young tourists is also still lacking because there is still garbage scattered around the tourist location area. Young tourists also do not apply health protocols when travelling in nature during the COVID-19 pandemic. Environmental conservation should regularly involve young tourists because they have a considerable influence. Young tourists who visit tourist objects will upload their activities during their trip to social media. If young tourists are engaged in positive activities such as nature conservation, it can create a sense of concern for nature for other young tourists who see their posts.

Meanwhile, cultural conservation got a good average score. Because the purpose of young tourists when they come to Silalahi Village is to witness its cultural activities and spread these cultural activities through social media so as to make other young tourists interested in coming to Silalahi Village. Young tourists also apply health protocols during cultural tours. Unfortunately, cultural activities such as dance performances are only available on big days. By comparing the two factors above, we get the result that environmental conservation should get more attention than cultural conservation.

To Increase awareness of the importance of environmental and cultural conservation for young tourists and local communities and support the sustainability of geotourism in the Toba Caldera, it is recommended to provide training on how to properly manage water and waste, carry out environmental and cultural conservation activities regularly by involving young tourists, impose sanctions on people who pollute the environment and destroy cultural objects, using social media as a platform to remind young tourists and local people about the importance of preserving the environment and culture, thereby increasing their awareness. Using environmentally friendly product packaging to reduce the impact of pollution due to plastic waste as well as provide training on the importance of implementing health protocols in the era of the COVID-19 pandemic. This research is limited to the conservation aspect so that further research is needed on other factors in supporting the development of geotourism.

\section{Acknowledgement}

The authors wish to thank Universitas Sumatera Utara for their valuable support of this study. The support is under the research grant TALENTA USU 2021 Contract Number: 481/UN5.2.3.1/PPM/SPP-TALENTA USU/2021.

\section{Paper Contribution to Related Field of Study}

This research contributes to urban planning and tourism to develop geotourism by implementing conservation aspects for young tourists during the COVID-19 pandemic in Silalahi Village. 


\section{References}

Andrady, A. L. (2011). Microplastics in the marine environment. Marine pollution bulletin, 62(8), 1596-1605.

Appleyard, D. (Eds). (1979). The Conservation of European Cities. Cambridge MA: MIT Press.

Atmanti, H. D., \& Purwanti, E. Y. (2021). The Impact of Waste on Domestic Tourist Visits to Pangaradan Beach, Banten Province. International Journal of Economics, Business Adn Accounting Researsh (IJEBAR), 5(2), 399-406.

Astuti, M. T. (2018). Strategi Pengembangan Wisata Bahari Di Gili Trawangan Kabupaten Lombok Barat Provinsi Nusa Tenggara Barat. National Conference of Creative Industry, 10(September 2018), 76-92.

Catana, M. M., \& Brilha, J. B. (2020). The role of UNESCO Global Geoparks in promoting geosciences education for sustainability. Geoheritage, $12,1$.

Dewar, K. (2011). Geotourism: the tourism of geology and landscapes and Global geotourism perspectives. Journal of Heritage Tourism, 6(2)

Dowling, R. K. (2014). Global Geotourism - An Emerging Form of Sustainable Tourism. Czech Journal of Tourism, 2(2), 59-79.

Gill, J. C. (2017). Geology and the Sustainable Development Goals. Episodes, 40, 70-76.

Ginting, N., Marpaung, B. O. Y., Sinaga, F. A., Narisa, N., \& Siregar, N. (2020). Geotourism and stakeholders: An approach to enhance geoconservation. IOP Conference Series: Earth and Environmental Science, 452(1).

Ginting, Nurlisa, Rahman, N. V., \& Delianur Nasution, A. (2020). A Comparative Study of Landmark on Heritage Tourism in Sumatra. Environment-Behaviour Proceedings Journal, 5(15), 221-227.

Ginting, Nurlisa, Rahman, V. N., Nasution, A. D., \& Dewi, N. A. (2021). Geotourism development through the public facilities in Geotrail Bakkara, Toba Caldera Geopark. Geojournal of Tourism and Geosites, 37(3), 914-920.

Hakim, L. (2020). COVID-19 and the Moment to Evaluate Tourism Euphoria, Indonesia. Journal of Indonesian Tourism and Development Studies, 8(2), 119-123.

Han, H., Kim, W., \& Kiatkawsin, K. (2017). Emerging youth tourism: fostering young travelers' conservation intentions. Journal of Travel and Tourism Marketing, 34(7), 905918.

Han, H., Yu, J., \& Kim, W. (2018). Youth travelers and waste reduction behaviors while traveling to tourist destinations. Journal of Travel and Tourism Marketing, 35(9), $1119-1131$.

Hayati, Y., Adrianto, L., Krisanti, M., Pranowo, W. S., \& Kurniawan, F. (2020). Magnitudes and tourist perception of marine debris on small tourism island: Assessment of Tidung Island, Jakarta, Indonesia. Marine pollution bulletin, 158, 111393.

Hermawan, H., \& Brahmanto, E. (2017). GEOWISATA: Perencanaan Pariwisata Berbasis Konservasi. Pekalongan, Jawa Tengah: Penerbit NEM.

Herrera-Franco, G., Montalván-Burbano, N., Carrión-Mero, P., Apolo-Masache, B., \& Jaya-Montalvo, M. (2020). Research trends in geotourism: A bibliometric analysis using the scopus database. Geosciences (Switzerland), 10(10), 1-29.

Hose, T. A. (1995). Selling the Story of Britain's Stone. Environ Interpret, 10 (2), 16-17.

Hose, T. A. (2000). European geotourism-geological interpretation and geoconservation promotion for tourists. Geological heritage: its conservation and management. Instituto Tecnologico Geominero de Espana, Madrid, 127-146

Hutauruk, M., Nasution, Z., \& Purwoko, A. (2018). Youth Participation in Geopark Kaldera Toba Tourism and Economic Development ( Case Study : Toba Samosir ). International Journal of Research, 05(20).

Jang, Y. C., Hong, S., Lee, J., Lee, M. J., \& Shim, W. J. (2014). Estimation of lost tourism revenue in Geoje Island from the 2011 marine debris pollution event in South Korea. Marine pollution bulletin, 81(1), 49-54

Kariminia, S., Sh. Ahmad, S., Hashim, R., \& Ismail, Z. (2018). Impact Assessment and Dynamic Management towards Sustainable Tourism in Antarctica. Journal of ASIAN Behavioural Studies, 3(8), 87.

Kemenparekraf/Baparekraf RI. (2021, 19 Juli). ISTC: Mendorong Percepatan Pariwisata Berkelanjutan di Indonesia. Accessed from https://kemenparekraf.go.id/ragampariwisata/ISTC\%3A-Mendorong-Percepatan-Pariwisata-Berkelanjutan-di-Indonesia

Kiatkawsin, K., \& Han, H. (2017). Young travelers' intention to behave pro-environmentally: Merging the value-beliefnorm theory and the expectancy theory. Tourism Management, 59, 76-88.

Kubalíková, L. (2019). Assessing geotourism resources on a local level: A case study from Southern Moravia (Czech Republic). Resources, 8(3).

Lee, Y. J., \& Jayakumar, R. (2021). Economic impact of UNESCO Global Geoparks on local communities: Comparative analysis of three UNESCO Global Geoparks in Asia. International Journal of Geoheritage and Parks, 9(2), 189-198.

Newcomb, R. M., \& Appleyard, D. (1981). The Conservation of European Cities. Geographical Review, 71(1).

Newsome, D., \& Dowling, R. (2010). Setting an agenda for geotourism. Geotourism: The tourism of geology and landscape, 1-12.

Manurung, H., \& Sinabariba, E. (2020). Indonesia Soft Power: Toba Caldera As Unesco Global Geopark 2020. Sociae Polites, 21(3), 121-135. 
Preko, A., Doe, F., \& Dadzie, S. A. (2019). The future of youth tourism in Ghana: motives, satisfaction and behavioural intentions. Journal of Tourism Futures, 5(1), 5-21.

Prykhodchenko, D. (2017). "Sustainable Geoscience and Geotourism" - An International Scientific Open Access Journal. Sustainable Geoscience and Geotourism, 0, 1-2.

Runa, I. W., Warnata, I. N., \& Anasta Putri, N. P. R. P. (2020). Conservation of Cultural Heritage Architecture and Development of Tourism in Denpasar, Bali. Journal of Architectural Research and Education, 1(2), 99-106.

Sadry, B. N. (2020). The Geotourism Industry in the 21st Century: the Origin, Principles, and Futuristic Approach. Florida, USA: Apple Academic Press Inc.

Simatupang, K. H., \& Ismanto, I. (2021). Covid-19 \& unesco global geopark kaldera toba: peluang dan tantangan pengembangan pariwisata berkelanjutan di kawasan danau toba. Verity - UPH Journal of International Relations, 13(25), 63-73.

Staffieri, S., Cavagnaro, E., \& Rowson, B. (2018). Change as a travel benefit: Exploring the impact of travel experiences on Italian youth. Research in Hospitality Management $7(2), 81-89$.

Sudiasmo, F., \& Muspita, N. C. (2020). Local wisdom in environment conservation : A study on a conservation and energy self-sufficient village Kearifan lokal dalam konservasi lingkungan : Studi pada desa konservasi dan mandiri energi. Masyarakat, Kebudayaan Dan Politik, 405-412.

Supriono, S. (2020). PENGEMBANGAN KONSERVASI WISATA BUDAYA MELALUI WISATA EVEN (Studi pada Pelaksanaan Festival Reyog Nasional di Kabupaten Ponorogo). Profit, 14(01), 69-74.

Tien, N. H., Dung, H. T., Vu, N. T., Doan, L., \& Duc, M. (2019). Risks of unsustainable tourism development in Vietnam. International Journal of Research in Finance and Management, 2(2), 81-85

Tirtanadi. (2016, 18 February). PENCEMARAN DANAU TOBA \& SOLUSI PENANGGULANGANNYA UNTUK MEWUJUDKAN DANAU TOBA "THE MONACO OF ASIA". Accessed from https://pdamtirtanadi.co.id/pencemaran-danau-toba-solusi-penanggulangannya-untuk-mewujudkan-danau-toba-the-monaco-of-asia/

Umar, S. B., \& Said, I. (2018). Conservation Challenges of Heritage Building Reuse in Nigeria: A review of decision-making models. Asian Journal of Environment-Behaviour Studies, 4(12), 16-36.

UN (2015). Resolution adopted by the General Assembly on 25 September 2015 (A/RES/70/1). New York: United Nation.

UNESCO (2006). Global Geoparks Network (SC/EES/2006/PI/GEOPARKS/1) [Online]. Available: https://unesdoc.unesco.org/ark:/48223/pf0000150007 [Accessed 5 February 2021].

UNWTO. (2020). COVID-19 and Transforming Tourism. Un.Org, August, 1-27. https://www.un.org/es/events/tourismday/

United Nations World Tourism Organization \& World Youth Student \& Educational Travel Confederation. (2008). Youth Travel Matters: Understanding the Global Phenomenon of Youth Travel, UNWTO: Madrid.

UNWTO-WYSE (2011), "The power of youth travel", Worldwide Youth in Science and Engineering, Madrid.

Wulung, S. R. P., Brahmantyo, B., \& Rosyidie, A. (2021). Konsep Kotak Geowisata dan Penerapannya di Destinasi Pariwisata Cekungan Bandung. Journal of Tourism Destination and Attraction, 9(2), 135-144.

Yousefloo, A., \& Babazadeh, R. (2020). Designing an integrated municipal solid waste management network: A case study. Journal of cleaner production, $244,118824$.

Yunusovich, S. S. (2018). Youth Tourism as a Scientific Research Object. Journal of Tourism \& Hospitality, 07(05), 7-9.

Zambrano-monserrate, M. A., Alejandra, M., \& Sanchez-alcalde, L. (2020). Indirect effects of COVID-19 on the environment. Science of the Total Environment, 728. 